\section{LINGUAGEM E ARQUITETURA DA INFORMAÇÃO EM WEBSITES PARA SURDOS}

\section{LANGUAGE AND INFORMATION ARCHITECTURE IN WEBSITES FOR DEAF}

\author{
Carla da Silva Flor ${ }^{1}$, Dra. \\ Tarcísio Vanzin ${ }^{2}$, Dr. \\ (1) Universidade Federal de Santa Catarina \\ e-mail: carla.flor@gmail.com \\ (2 Universidade Federal de Santa Catarina \\ e-mail:tvanzin@gmail.com
}

Surdez, websites, navegação.

Este artigo apresenta a primeira etapa de uma pesquisa que buscou criar recomendações para a criação de sites acessíveis a surdos. Sabe-se que o público surdo pré-linguístico, ou seja, aquele que se tornou surdo antes da aquisição da linguagem, tem dificuldades com o português, inclusive escrito, devido à falta do feedback auditivo. Em decorrência disso, no Brasil os surdos utilizam uma língua própria, a Língua Brasileira de Sinais (Libras). O intuito desta primeira fase da pesquisa foi justamente entrevistar tradutores/intérpretes de português/Libras para verificar como deve ser esse processo tradutório nos websites. Como resultado, obteve-se uma série de relatos que podem ser observados na construção de websites futuros.

Deaf, websites, browsing

This article represents the first stage of a research which aimed to create recommendations for the creation of web sites accessible to deaf. It is known that the pre-linguistic deaf public, in other words, those who became deaf before language acquisition, have difficulty with Portuguese, including the written form, due to the lack of auditory feedback. Because of that, in Brazil, deaf use their own language, the Brazilian Sign Language (Libras). The purpose of the first stage of the research was exactly to interview Portuguese/Libras translators/interpreters to check on how the website translation process must be. Thus, a range of reports, which can be observed on the construction of future websites, were obtained.

\section{Introdução}

Atualmente muitas informações do governo, das universidades, dos sistemas bancários ou relacionadas ao lazer só estão disponíveis de forma on-line. Essas informações, no entanto,

normalmente estão publicadas de maneira textual, enquanto uma parcela da população mundial é
Realização:

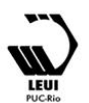




\section{$16^{\circ}$ \\ ERGODESIGN USIHC CINAHPA}

$16^{\circ}$ Ergodesign - Congresso Internacional de Ergonomia e Usabilidade de Interfaces Humano Tecnológica: Produto, Informações Ambientes Construídos e Transporte

$16^{\circ}$ USIHC - Congresso Internacional de Ergonomia e Usabilidade de Interfaces Humano Computador

CINAHPA | 2017 - Congresso Internacional de Ambientes Hipermídia para Aprendizagem. afetada pela surdez profunda pré-linguística, que traz prejuízos para a compreensão da leitura. Temse conhecimento que cerca de $80 \%$ das pessoas que nasceram ou que se tornaram surdas antes da aquisição da linguagem, que ocorre até por volta dos 4 anos, têm dificuldades de relacionar as palavras escritas, por serem estas as representações visuais de signos auditivos (DEBEVC; KOSEC; HOLZINGER, 2010, 2011). Sendo assim, os websites textuais mostram-se impróprios para estas pessoas, pois mesmo que seus conteúdos não estejam disponibilizados na forma de áudio, os surdos apresentarão dificuldades na compreensão dos textos.

Como pode-se perceber, a modalidade linguística natural do surdo não é a oral, e sim a gestual. No Brasil, a língua utilizada é a Língua Brasileira de Sinais (Libras), que foi reconhecida como língua oficial dos surdos em 2002 (BRASIL, 2002). Na prática, a Libras é uma língua visuoespacial cujo registro se dá na forma de gravação de vídeos, pois apesar de existir uma modalidade escrita, a maioria dos surdos não recebe a devida alfabetização dos sinais escritos nas escolas.

Apesar do seu reconhecimento, atualmente ainda são poucos os sites que disponibilizam as informações em Libras e alguns fornecem softwares de tradução automática de conteúdo.

Porém esses softwares nem sempre realizam uma tradução semântica adequada, pois a língua portuguesa e a língua de sinais apresentam diferenças linguísticas significativas. Até mesmo para um tradutor humano a tradução entre as duas línguas impõe desafios, visto que a Libras é uma língua recente e ainda não desfruta de um vocabulário tão amplo como a língua portuguesa.

Na web, a tradução equivocada do português para Libras pode trazer prejuízos tanto para a leitura dos conteúdos em si, quanto para a navegação em busca de uma determinada informação. Além disso, como os sites são organizados em categorias e subcategorias, a dificuldade de leitura do português e as diferenças linguísticas da Libras podem ter influência no acesso aos hiperlinks em função da organização dos conteúdos. Com base nisso, uma ampla pesquisa buscou criar recomendações para a criação de websites que suprissem as necessidades dos usuários surdos na navegação, sobretudo em relação a como o processo tradutório deve ser realizado. A pesquisa realizou-se em quatro etapas, como mostra a Figura 1, no entanto, neste artigo estão descritos os métodos e resultados apenas da primeira etapa, que consistiu em uma entrevista semiestruturada realizada com tradutores/intérpretes de portuguêsLibras. Essa entrevista inicial foi realizada com esse público por serem os tradutores/intérpretes os mediadores entre a língua portuguesa e a língua de sinais e, portanto, seriam eles as pessoas mais indicadas para fornecerem subsídios sobre as características que devem ter os hiperlinks e conteúdos em Libras.

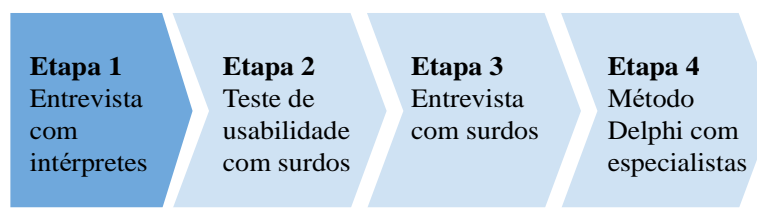

Figura 1 - Etapas da realização da pesquisa. Fonte: Os autores.

Uma breve revisão da literatura é mostrada a seguir e, posteriormente, os detalhes do método utilizado para as entrevistas e os resultados são descritos.

\section{Revisão da literatura}

\subsection{Linguagem dos websites}

A principal função de um website é comunicar com o seu público-alvo. Portanto, a linguagem utilizada em um website é de extrema importância para que a mensagem chegue ao usuário e para que ele possa se locomover no site ao clicar nos hiperlinks. Atualmente a maioria dos websites adota como linguagem principal a textual, muito embora os surdos apresentem dificuldades com a língua portuguesa. A linguagem textual, assim como a oral, pode assumir diferentes funções com a finalidade de comunicar. Jakobson (1987) identificou seis funções possíveis para a linguagem, que podem ser adaptadas para aplicação aos hiperlinks da web. A primeira delas, a função referencial ou denotativa, transmite a informação objetivamente em terceira pessoa, sem utilizar metáforas. Muito utilizada também em
Realização:
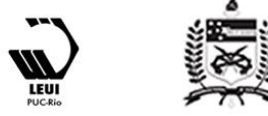


\section{$16^{\circ}$ \\ ERGODESIGN USIHC CINAHPA}

$16^{\circ}$ Ergodesign - Congresso Internacional de Ergonomia e Usabilidade de Interfaces Humano Tecnológica: Produto, Informações Ambientes Construídos e Transporte

$16^{\circ}$ USIHC - Congresso Internacional de Ergonomia e Usabilidade de Interfaces Humano Computador

CINAHPA | 2017 - Congresso Internacional de Ambientes Hipermídia para Aprendizagem. websites, principalmente na navegação, categoriza os conteúdos da forma mais objetiva possível. A segunda função, a emotiva ou expressiva, pelo contrário, transmite a mensagem subjetivamente, em primeira pessoa. Na web é comum encontrá-la em sites de $e$-commerces para fazer o cliente se sentir próximo do site, com a personalização de algumas áreas e utilização de pronomes em primeira pessoa, como, por exemplo, meus desejos, minha lista de compras, minha cesta, meus pedidos. A terceira função, a conativa ou apelativa, utiliza vocativos e imperativos para convencer, influenciar, sugerir, convidar e apelar. Também pode utilizar verbos em segunda e terceira pessoa, como em você não pode deixar de assistir ao filme! Na web é encontrada em sites comerciais induzindo o usuário a realizar compras. A quarta função, a metalinguística, explica o código utilizado na mensagem entre o emissor e o receptor. Em websites pode ser encontrada em páginas destinadas a explicar a estrutura do site (mapa do site) e de como utiliza-lo (acessibilidade, plugins necessários, etc.). A quinta função, a função fática, prolonga ou termina a comunicação entre emissor e receptor, verifica o funcionamento do canal ou atrai a atenção do receptor. $\mathrm{Na} w e b$ pode ser encontrada em sites corporativos para iniciar uma interação com o cliente, e também para incentivar a permanência do usuário, como em lojas de vendas on-line, no link continue comprando, ou em sites de notícias, no link leia mais, saiba mais. Por último, a sexta função, a poética, dispõe o código de tal maneira que este assume um significado especial. Em interfaces da web pode-se encontrar um tipo de navegação conhecido como nuvem de tags, cujo tamanho (código) determina a importância das palavras no site (DIAS, 2014; JAKOBSON, 1987; VESTERGAARD; SCHRODER, 2004).

Apesar dessas funções serem utilizadas na web para facilitar a comunicação com o público em geral, como já foi mencionado anteriormente, o público surdo pré-linguístico apresenta dificuldades com a língua portuguesa. Portanto, verificar se essas funções são adequadas para o público surdo é importante para poder-se elaborar sites voltados a eles. Também é necessário compreender quais são essas dificuldades e até que ponto elas afetam a sua compreensão na leitura de textos.

\subsection{Surdos e a língua portuguesa}

A falta do input auditivo reflete tanto na aprendizagem da língua oral, quanto da escrita, pois as palavras escritas relacionam-se com os fonemas, e como o surdo não os ouve, não é capaz de relacioná-los (OTTAVIANO et al., 2010; PERLIN, 2012; DEBEVC; KOSEC; HOLZINGER, 2011). A aquisição de novas palavras e conceitos no vocabulário do surdo é um desafio constante, o que reflete na diferença da habilidade de leitura entre surdos e ouvintes. A dificuldade de leitura e escrita da língua portuguesa pelos surdos passa pelas relações sintático-semânticas, que vão desde a organização da gramática da frase até o significado das palavras, que dão coerência e sentido aos textos. Dentre as dificuldades que apresentam estão o uso inapropriado dos pronomes demonstrativos, possessivos e pessoais; o uso incorreto ou a ausência de preposições; o uso inadequado de conjunções; a falta de conjugação dos verbos (utilizam o infinitivo); a ausência do uso de verbos de ligação e de concordância verbal; a não distinção entre verbo, substantivo e adjetivo; a dificuldade de produção e interpretação de textos sem gravuras como apoio; a inexistência de pontuação nas frases; a dificuldade com os tempos verbais; o uso inadequado de adjetivos e artigos que indicam gênero; a inserção de palavras inventadas e com significados não convencionais; e a ausência de coesão textual para que se possa entender o texto (QUEVEDO, 2013).

Diferentemente dos alunos ouvintes, que já conhecem a língua oral e podem se apoiar no conhecimento prévio que dela possuem, os alunos surdos não conhecem todas as palavras ou estruturas e geralmente não possuem o conhecimento necessário capaz de atribuir sentido em uma leitura (PEREIRA, 2009).

\subsection{Organização do conhecimento categórico}

Surdos não fazem uma leitura de cima para baixo como os ouvintes, nem utilizam o contexto, lendo palavra por palavra, o que sobrecarrega a memória
Realização:
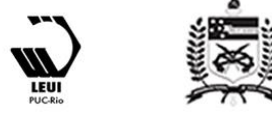


\section{$16^{\circ}$ \\ ERGODESIGN USIHC CINAHPA}

$16^{\circ}$ Ergodesign - Congresso Internacional de Ergonomia e Usabilidade de Interfaces Humano Tecnológica: Produto, Informações Ambientes Construídos e Transporte

$16^{\circ}$ USIHC - Congresso Internacional de Ergonomia e Usabilidade de Interfaces Humano Computador

CINAHPA | 2017 - Congresso Internacional de Ambientes Hipermídia para Aprendizagem. de trabalho. Além disso, costumam armazenar mais detalhes na Memória de Longo Termo (MLT) do que as relações entre conceitos (FAJARDO; ABASCAL; CAÑAS, 2004).

Em relação à capacidade de categorização, alguns estudos permitiram observar as habilidades de categorização de conteúdos verbais dos surdos em relação aos ouvintes. Em Fajardo et al. (2008), por exemplo, os surdos foram tão precisos quanto os ouvintes nos testes de categorização, mas pareciam ter utilizado outras estratégias de busca, como a pesquisa visual dos itens da página para encontrar o conteúdo. Já em Fajardo, Abascal e Cañas (2008), os autores utilizaram um teste de categorização mais complexo, chamado de Tarefa de Analogia Verbal. Desta vez, os resultados permitiram observar que a eficiência na aplicação de categorias verbais foi menor em surdos do que em ouvintes. Ao final do experimento, os autores concluíram que os surdos não eram capazes de ativar automaticamente o conhecimento necessário para resolver a tarefa, pois o formato verbal não era apropriado para os usuários da língua de sinais acessarem o seu conhecimento categórico. Ao invés disso, os surdos poderiam utilizar a sua memória visuoespacial para compensar a falta de proficiência na leitura ao buscar informações em um menu.

Um terceiro experimento foi realizado por Fajardo Parra e Cañas (2010) em que realizaram um Teste de Associação de uma Única Palavra e um Teste de Analogia Verbal. Ao final do primeiro teste, os autores descobriram que ambos os perfis de participantes (surdos e ouvintes) associaram as mesmas palavras mais frequentemente às categorias do que aos itens dentro da categoria. No segundo teste, os surdos resolveram menos analogias do que os participantes ouvintes, sobretudo as analogias coordenadas, em que o participante tinha que encontrar a relação entre dois itens que pertenciam a uma mesma categoria (por exemplo, pé está para mão, assim como piano está para guitarra) e cujo grau de dificuldade era maior.

\subsection{Ambiguidades lexicais no processo de tradução}

Além dos problemas já mencionados com relação às dificuldades dos surdos com a língua portuguesa e com a categorização de itens, há ainda a dificuldade de traduzir/interpretar do português para Libras as palavras que são lexicalmente ambíguas. Essas palavras geraram ambiguidade por não possuírem equivalentes diretos ou por possuírem mais de um signo representativo na língua que será traduzida. Essas ambiguidades ocorrem pelo uso de palavras homônimas ou polissêmicas. Na homonímia uma mesma palavra pode ter significados distintos que não estão relacionados, como por exemplo, a palavra torcer, que exerce o sentido de girar, em girar a tampa, $\mathrm{e}$ de desejar, em torcer para o time vencer. Já na polissemia, uma mesma palavra pode ser ter diferentes sentidos, mas cada um relacionado entre si, como as palavras guarda-chuva e guarda-roupa, em que o termo guarda é utilizado em ambos os casos com o sentido de proteger. Quando a palavra polissêmica ou homonímica é traduzida do português para Libras, pode ocorrer de haver diferentes sinais que a represente, mas nenhum correspondente ao significado exato da palavra no contexto da frase original em português (ROSA; BIDARRA, 2012). O oposto também pode ocorrer, como quando um sinal representa várias palavras em português. Seria o caso de saúde, sadio e saudável que são representados pelo mesmo sinal. Neste caso a frase "ingerir alimento saudável, ajuda preservar a saúde", exemplificada por Bidarra e Martins (2012, p. 9), se tornaria ambígua, pois tanto a palavra saudável quanto saúde têm sinais idênticos em Libras.

Alguns métodos podem ser utilizados pelo tradutor para sanar o problema das ambiguidades. Um deles seria o uso da datilologia, uma espécie de soletração manual do português, mas essa técnica só funciona quando os surdos já possuem o conhecimento do significado da palavra. Outra forma seria substituir a palavra por outra equivalente. É necessário compreender o significado da palavra na língua de origem, dentro do contexto frasal, para que o sentido original não seja perdido.
Realização:
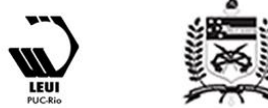


\section{$16^{\circ}$ \\ ERGODESIGN USIHC CINAHPA}

Assim como nos casos de palavras polissêmicas e homônimas, há também expressões metafóricas que podem ser representadas da mesma maneira ou de forma diferente entre as duas línguas. A expressão morrer de rir, por exemplo, que significa rir muito, é representada semanticamente como torcer barriga em Libras (NASCIMENTO; NASCIMENTO, 2010).

Infelizmente, tanto na Libras quanto em qualquer outra língua não há repertório vocabular que dê conta de nomear todos os objetos ou conceitos existentes, e por isso acabam surgindo as homonímias e as polissemias. A Libras apresenta mais dificuldades aos tradutores/intérpretes do que as línguas orais, devido ao fato dos símbolos constitutivos da língua possuírem na estrutura morfológica, sintática e semântica, características relevantes como expressões faciais, movimento de olhos e de mãos que precisam ser analisadas com atenção durante o processo da interpretação (BIDARRA; MARTINS, 2012). No entanto, se o processo de tradução já apresenta os diversos complicadores mencionados para tradutores/ intérpretes humanos, esses problemas podem ser ainda mais complexos para sistemas de informação criados com o intuito de aumentar a acessibilidade digital do público surdo.

\section{Método}

Com base nas dificuldades dos surdos com a língua portuguesa e nas ambiguidades que podem surgir no processo de tradução entre esta língua e a língua de sinais, começou-se a questionar qual seria a forma mais adequada para elaboração de sites que atendessem as necessidades dos usuários surdos na internet. Como pôde-se ver na breve revisão apresentada anteriormente, os sites utilizam funções de linguagens específicas para comunicar com o público, de forma a facilitar a navegação dos usuários entre os hiperlinks. Porém, como os usuários surdos possuem uma língua própria, seria necessário verificar qual a linguagem mais adequada para eles e pesquisar como solucionar os potenciais problemas de tradução decorrentes das ambiguidades já mencionadas. Além disso, a questão da organização do conhecimento categórico poderia ter uma influência direta sobre a $16^{\circ}$ Ergodesign - Congresso Internacional de Ergonomia e Usabilidade de Interfaces Humano Tecnológica: Produto, Informações Ambientes Construídos e Transporte

$16^{\circ}$ USIHC - Congresso Internacional de Ergonomia e Usabilidade de Interfaces Humano Computador

CINAHPA | 2017 - Congresso Internacional de Ambientes Hipermídia para Aprendizagem. arquitetura dos sites, uma vez que os surdos apresentam mais dificuldades em testes de categorização quando comparado aos ouvintes (FAJARDO; ABASCAL; CAÑAS, 2008; FAJARDO; PARRA; CAÑAS, 2010). Apesar dos estudos evidenciarem a necessidade de utilização da língua de sinais em websites para surdos, uma questão que poderia minimizar o empenho gasto na produção e transmissão desses vídeos seria a utilização de tradutores automáticos ou da escrita de sinais, mas o desempenho desses recursos precisariam ser avaliados. A fim aprofundar nesses quesitos, realizou-se entrevistas semiestruturadas com tradutores/intérpretes, que são mediadores no intercâmbio linguístico Português-Libras e que, portanto, poderiam fornecer informações empíricas e aprofundadas sobre as necessidades do público surdo. As perguntas foram elaboradas tendo como base as questões apontadas, conforme o Quadro 1.

Elaboradas as perguntas, o próximo passo foi identificar o perfil dos participantes da pesquisa para que os resultados fossem confiáveis. As coletas de dados foram realizadas presencialmente (quatro), por videoconferência (duas) e por formulário eletrônico (cinco) e levaram em torno de 40 minutos para serem respondidas.

1) De acordo com as funções da linguagem (referencial ou denotativa (por exemplo página inicial, serviços, etc.), emotiva ou expressiva (minha cesta de compras), conotativa ou apelativa (compre, acesse, etc.), metalinguística (mapa do site) e poética (home, nuvem de tags), que tipo de linguagem é mais utilizada pelo surdo?

2) Considerando a sua experiência na comunicação de surdos, você considera que os surdos preferem utilizar a linguagem mais pessoal (em primeira pessoa) ou mais formal (em terceira pessoa)? Ou mais coloquial (expressões cotidianas)?

3) Você considera que a linguagem atual dos websites são adequados para surdos?

4) Que tipo de ambiguidades você identifica nos sites da web? Por exemplo, os termos contato e home são inteligíveis para os surdos? Como são traduzidos? Com relação ao uso de metáfora (por exemplo, home), como você traduziria?

5) Identifique alguns exemplos de termos polissêmicos (mesma origem lexical) e homonímicos (totalmente diferentes) que são encontrados em sites da web. Como você acha que poderiam ser traduzidos?

6) Que tipo de recurso você utiliza para diferenciar palavras que são traduzidas por um mesmo sinal (por exemplo saúde, sadio e saudável)?

7) Você acha que a estrutura hierárquica das páginas ajuda a
Realização:
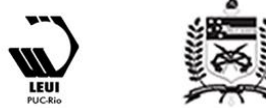

UNIVERSIDADE FEDERAL DE SANTA CATARINA 


\section{$16^{\circ}$ \\ ERGODESIGN USIHC CINAHPA}

$16^{\circ}$ Ergodesign - Congresso Internacional de Ergonomia e Usabilidade de Interfaces Humano Tecnológica: Produto, Informações Ambientes Construídos e Transporte

$16^{\circ}$ USIHC - Congresso Internacional de Ergonomia e Usabilidade de Interfaces Humano Computador

CINAHPA | 2017 - Congresso Internacional de Ambientes Hipermídia para Aprendizagem. diminuir as ambiguidades existentes (por exemplo, laranja e sábado possuem o mesmo sinal, mas para chegar até laranja, o surdo teve que acessar o item frutas e verduras)?

8) Você considera que os termos de uma estrutura de navegação, por estar isolado de seu contexto (o conteúdo distante) pode aumentar a ambiguidade? Considera que se fosse possível trazer elementos desse contexto ajudaria a navegação? Você considera que incluir informações adicionais, além do termo traduzido, poderia ajudar a diminuir a polissemia e a homonímia?

9) Você considera que seria viável a utilização de um tradutor automático para traduzir os itens de navegação de um website? Explique o porquê.

10) Em relação do SignWritting, você considera que ele é bem conhecido entre os surdos? Considera viável utilizá-lo em vez de vídeos em língua de sinais nos sites da web?

Quadro 1 - Roteiro de perguntas pré-elaboradas para entrevista semi-estruturada com tradutores/intérpretes

Libras/Português. Fonte: Flor (2016).

\subsection{Perfil dos entrevistados}

A pesquisa foi realizada com 11 tradutores/ intérpretes de Libras/Português que possuem de um ano e meio a 20 anos de experiência na área. Quatro participantes são intérpretes em universidades, quatro em institutos federais e três em escolas básicas. Nove dos 11 entrevistados relataram já terem trabalhado com surdos que apresentavam dificuldades consideráveis com a língua portuguesa. A maioria produz ou já traduziu material publicado na web, como conteúdos de materiais didáticos, de notícias, de vídeos institucionais, de entrevistas ou propriamente websites. Apenas um dos entrevistados disse não ter nenhuma experiência com tradução de conteúdos para web.

\section{Resultados}

Os dados das entrevistas com tradutores/intérpretes foram coletados e posteriormente analisados pelo Discurso do Sujeito Coletivo (DSC). Essa técnica consiste na construção de um discurso-síntese, formulado na primeira pessoa do singular, a partir de fragmentos individuais dos entrevistados (expressões-chave), que, reunidos por similaridade (ideias-centrais), dão sentido ao discurso. O DSC utiliza a primeira pessoa do singular porque "o discurso coletivo é a junção dos discursos individuais, respeitando os sentidos e o nível de compartilhamento. A rigor, os discursos individuais nada mais são do que discursos coletivos enunciados por apenas uma pessoa" (GONDIM; FISCHER, 2009, p. 14).

Para a análise das entrevistas realizadas com tradutores/intérpretes, os depoimentos foram separados com base nas perguntas efetuadas e tabulados para a seleção das expressões-chave. Tais expressões foram agrupadas por semelhança, dando origem às ideias centrais. $\mathrm{O}$ resultado, de acordo com as perguntas efetuadas, é mostrado a seguir:

\section{1) Em relação às funções da linguagem} (referencial ou denotativa, emotiva ou expressiva, conotativa ou apelativa, metalinguística e poética)

As respostas dos participantes evidenciaram a dificuldade de generalização da utilização de uma função da linguagem, por conta da diversidade do público alvo. Cinco intérpretes relataram seguir o gênero do texto de partida e o objetivo da mensagem conforme solicitado pelo contratante, sem alterar a função da linguagem apresentada no texto. De acordo com Quadros e Karnopp (2004), os intérpretes devem assumir papel secundário no discurso, tornando-se passivos e neutros, embora a simples reprodução de palavras em sinais, muitas vezes, não possibilite o entendimento do significado da mensagem, que pode variar de acordo com o contexto e com as pessoas que interagem.

Dois tradutores/intérpretes relataram utilizar mais a função apelativa, uma vez que o público surdo que estão acostumados a lidar é discente: "você tem que incentivá-lo ao estudo, usar a linguagem mais apelativa. Tentando passar a ideia de que o que estou vendendo é algo bom e que ele deve assistir até o final. Tem que ser cativante". Em relação aos websites, outros cinco participantes responderam que a função denotativa é mais direta, e devido à dificuldade que os surdos têm com o português, ficaria mais fácil compreender o que eles têm que fazer: "para os sites eu acho que a função denotativa é a mais fácil, porque como a maioria deles têm um português mais simples, menos vocabulário, talvez fica mais claro o que ele precisa fazer". Em relação à linguagem emotiva ou expressiva, quatro intérpretes relataram ser uma linguagem bastante utilizada na interpretação com
Realização:

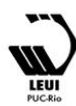




\section{$16^{\circ}$ \\ ERGODESIGN USIHC CINAHPA}

os surdos: "as marcações de pronome são sempre muito fortes". O Quadro 2 apresenta um resumo das opiniões dos tradutores/intérpretes sobre o uso das funções da linguagem com surdos, mostrando que as funções referencial ou denotativa e emotiva ou expressiva foram as mais citadas pelos intérpretes.

\begin{tabular}{|l|c|c|}
\hline Função da linguagem & $\begin{array}{c}\text { Escolha dos } \\
\text { participantes }\end{array}$ & $\begin{array}{c}\text { Rejeição dos } \\
\text { participantes }\end{array}$ \\
\hline $\begin{array}{l}\text { Referencial ou } \\
\text { denotativa }\end{array}$ & 5 & 1 \\
\hline Emotiva ou expressiva & 4 & 0 \\
\hline Conotativa ou apelativa & 2 & 1 \\
\hline Metalinguística & 0 & 1 \\
\hline Poética - metafórica & 0 & 1 \\
\hline
\end{tabular}

Quadro 2 - Escolha dos participantes em relação ao uso das funções da linguagem.

Fonte: Elaborado pelos autores.

Em relação aos websites, um dos entrevistados esclareceu que, como o público que acessa um determinado site é variado, têm-se que criar um padrão de linguagem, evitando, por exemplo, os regionalismos: "a gente cria um padrão, como se esse perfil de público fosse um só. A gente evita, por exemplo, regionalismos na língua de sinais". Essa fala é importante porque, diferentemente da língua portuguesa que é bastante padronizada, a língua de sinais ainda está em expansão e muitos sinais novos são criados a cada dia em comunidades localizadas. Apesar que não comprometerem completamente a comunicação, os regionalismos também geram ambiguidades e devem ser evitados, pois determinados sinais podem possuir significados distintos em diferentes regiões (BRASIL, 2009; MARTINS, 2013).

Apesar da maioria dos intérpretes terem relatado que fazem a tradução com base no texto, três deles também concordaram que é necessário se aproximar mais da língua de sinais, da língua de chegada e da cultura do público surdo, conforme evidencia esse trecho do discurso: "O surdo prefere quando parece que aquela mensagem foi pensada na língua de sinais. [...] traduzir até que se aproxime da linguagem comum para aquela pessoa". Para exemplificar, um dos intérpretes mencionou que traduziu o termo minha mochila (uma metáfora análoga ao carrinho de compras encontrado em lojas on-line, mas voltado para a $16^{\circ}$ Ergodesign - Congresso Internacional de Ergonomia e Usabilidade de Interfaces Humano Tecnológica: Produto, Informações Ambientes Construídos e Transporte

$16^{\circ}$ USIHC - Congresso Internacional de Ergonomia e Usabilidade de Interfaces Humano Computador

CINAHPA | 2017 - Congresso Internacional de Ambientes Hipermídia para Aprendizagem. compra de cursos on-line) de uma maneira mais apropriada na língua de sinais, já que ele supôs que a metáfora não seria compreendida pelo surdo: " $\mathrm{eu}$ disse aquelas informações (você pode escolher cursos que você vai fazer, não agora, mas que você tem interesse de se matricular) na língua de sinais, quase que esquecendo o texto (minha mochila)".

\section{2) Em relação à linguagem formal e informal}

Quanto à linguagem formal ou informal, as duas possibilidades existem em língua de sinais. Em relação ao que utilizam mais no cotidiano, sete tradutores/intérpretes afirmaram que preferem utilizar a linguagem mais informal para se aproximar de um público com pouca habilidade no português, pois "não adianta você ser muito formal e não atingir o público-alvo". Apenas um dos intérpretes prefere ser mais formal. Os demais participantes preferiram não se posicionar em relação à formalidade ou à informalidade. Argumentaram que a tradução vai depender do público-alvo, do texto original ou do que foi solicitado pelo cliente (contratante). Cabe ressaltar, no entanto, que o contexto de tradução para conteúdos escritos pode demandar uma formalidade maior do que o contexto de interpretação em que os intérpretes estão mais acostumados a atuar, e no qual predomina a pessoalidade.

Outro ponto relacionado à língua de sinais é a utilização de exemplos. Esse recurso é bastante explorado, como relata este entrevistado: " $n a$ cultura surda é muito comum você utilizar exemplos. Então sempre tem analogias, exemplos, contrastes...". Além dos exemplos, uma forma de se aproximar da cultura surda é utilizar todos os recursos visuais disponíveis.

Uma das questões evidenciadas pelos tradutores/ intérpretes é que muitos dos surdos têm dificuldades com o português e com a língua de sinais, já que muitas vezes a aprendizagem desta língua é tardia, e como não aprendem desde cedo em casa, com os pais, só passam a ter contato com ela anos mais tarde ou só na adolescência.

\section{3) Em relação aos websites atuais}

Realização:

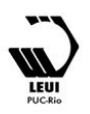




\section{$16^{\circ}$ \\ ERGODESIGN USIHC CINAHPA}

A maioria dos intérpretes pontuou que o predomínio nos websites existentes ainda é a informação escrita e não a visual. O ideal, principalmente para o surdo que não domina o português e é sinalizante, é que os sites estejam acessíveis em língua de sinais e utilizem recursos visuais. Apenas dois intérpretes concordaram que os websites atuais são adequados para surdos, mas somente quando a linguagem é pontual e direta e o surdo for acostumado a utilizar a web, pois neste caso ele se apropria da linguagem existente.

Para os intérpretes não basta simplesmente traduzir do português para a língua de sinais, "teria que ser pensado tudo em uma estrutura diferente. Até mesmo onde que vai aparecer a imagem, o intérprete, em que locais, como que ele vai clicar, até a própria usabilidade". A janela do intérprete tem que ser de fácil acesso: "você passe o mouse e o intérprete já sinaliza aquilo que está dizendo, isso facilita. (...) Poderia ser uma janela pequena, só com o que tem escrito na tela, por exemplo, iniciar, exercícios, dúvidas (...) seria o sinal basicamente".

Atualmente, no entanto, os poucos sites que são traduzidos nem sempre são de fácil acesso: "você quer ter acesso à língua de sinais, você tem que clicar em várias abas para depois acessar a língua de sinais. Eu acho que isso é um complicador". De fato, os critérios ergonômicos de Bastien e Scapin (1993) e os sete princípios de Norman (2006) já indicam que é necessário diminuir o número de passos e simplificar a estrutura das tarefas para se ter uma boa usabilidade. Por outro lado, os vídeos acessíveis em mouse over também podem incomodar quem não os utilizam. Disponibilizar um botão para a ativação dos vídeos em mouse over contribui para permitir o controle explícito dos usuários.

Os intérpretes relataram que há poucos sites traduzidos para Libras. Exemplificaram com os sites do IFSC Palhoça (Figura 2), do Letras Libras da UFSC (Figura 3), e do Prevenção dos

Problemas Relacionados ao Uso de Drogas (Figura 4). Em relação a este último, o tradutor/intérprete explica: "ele não é tão bilíngue, porque ele não utiliza tanto o português. Eu acho que seria $16^{\circ}$ Ergodesign - Congresso Internacional de Ergonomia e Usabilidade de Interfaces Humano Tecnológica: Produto, Informações Ambientes Construídos e Transporte

$16^{\circ}$ USIHC - Congresso Internacional de Ergonomia e Usabilidade de Interfaces Humano Computador

CINAHPA | 2017 - Congresso Internacional de Ambientes Hipermídia para Aprendizagem. interessante o português, para o surdo poder comparar, mas tem que ter essa parte em língua de sinais também". Neste site, há uma valorização da língua de sinais, mas falta o português, uma vez que atualmente a filosofia adotada no Brasil é o Bilinguismo (FLOR; VANZIN; ULBRICHT, 2013; PERLIN; STROBEL, 2006).

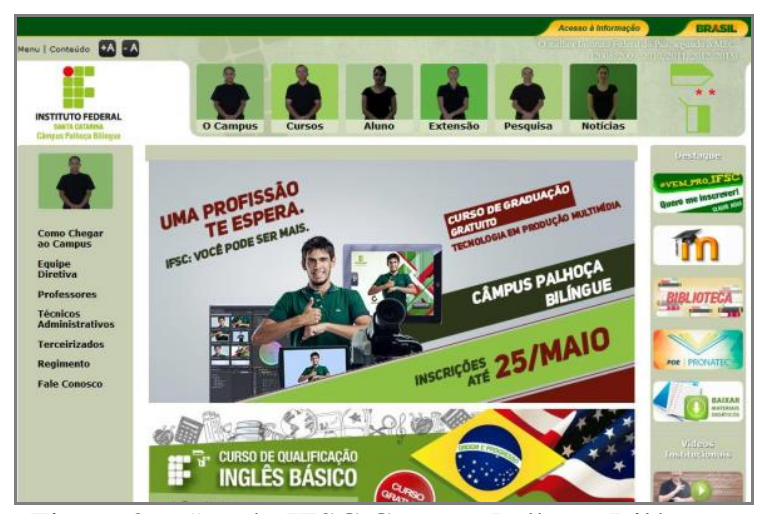

Figura 2 - Site do IFSC Campus Palhoça Bilíngue. Fonte: Instituto Federal de Santa Catarina (2015).

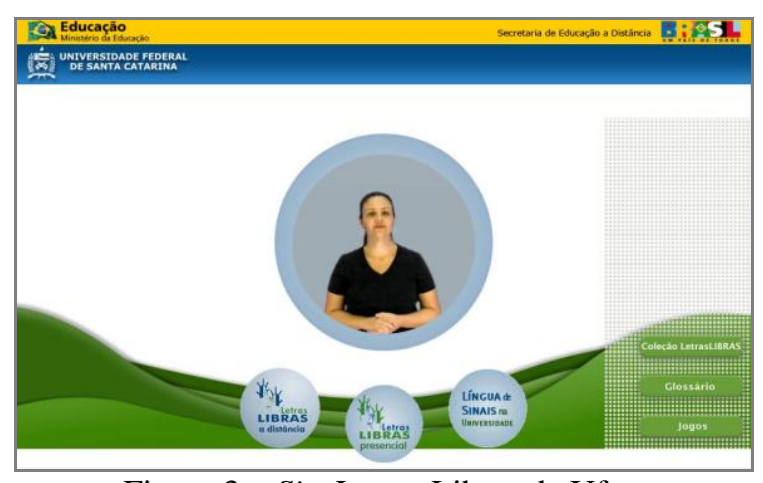

Figura 3 - Site Letras Libras da Ufsc.

Fonte: Universidade Federal de Santa Catarina (2015).

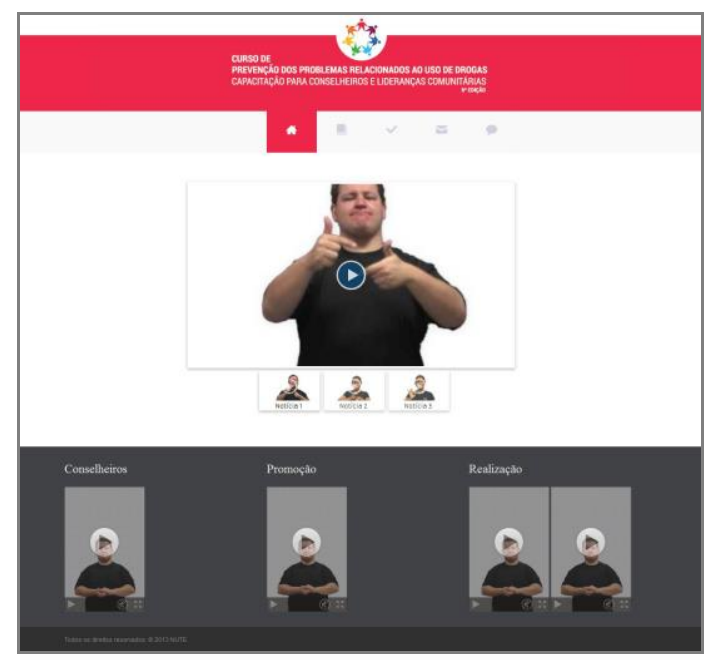

Realização:

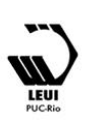




\section{$16^{\circ}$ \\ ERGODESIGN USIHC CINAHPA}

Figura 4 - Site do programa Prevenção dos Problemas Relacionados ao Uso de Drogas. Fonte: Prevenção dos Problemas Relacionados ao Uso de Drogas (2015).

\section{4) Em relação às ambiguidades e uso de metáforas (home, contato)}

Em relação às ambiguidades e metáforas, todos os tradutores/intérpretes expressaram que é possível encontrar, na língua de sinais, elementos que se aproximem do significado dos termos ambíguos ou metafóricos, sem utilizar uma tradução literal. No estudo da tradução, utiliza-se o termo Equivalência para buscar uma tradução apropriada para a língua e cultura de chegada, mesmo que seja necessário descartar algum aspecto formal da língua de partida (ROSA, 2014).

No que se refere à palavra contato, quatro dos entrevistados afirmaram que talvez os surdos entenderiam a tradução literal para o sinal e outros quatro consideraram que a tradução literal não seria adequada, pois o sinal de contato em Libras significa contato físico entre pessoas. De fato, no Novo Deit-Libras (CAPOVILLA; RAPHAEL; MAURICIO, 2009) constam três entradas para o termo contato, sendo dois deles relacionados com comunicação e relação de proximidade, enquanto apenas o terceiro é usado para a internet, mas sua validade[1] só foi confirmada no curso de LetrasLibras da UFSC e no estado do Rio Grande do Sul. Para exemplificar, então, como ficaria o termo contato traduzido para Libras, um dos tradutores/intérpretes sugeriu da seguinte forma: "Clique neste botão se você tiver alguma dúvida, um questionamento, quiser uma sugestão". Já os outros entrevistados sugeriram que o tradutor saiba o contexto para explicar de outro modo, utilizando a forma de contato em si (e-mail, telefone, etc.) ou um diálogo como fale conosco.

Com relação ao termo home, a maioria também afirmou que não utilizaria o termo literal traduzido para o sinal casa. Algumas propostas de tradução para o termo foram os sinais de começar, começo, voltar + início, página inicial, início e página principal. Já para a metáfora visual de $\mathrm{Meu}$ carrinho de compras, um dos entrevistados sugeriu que o tradutor faça uma espécie de brincadeira ao pegar os elementos a serem comprados e jogá-los para dentro da imagem do carrinho, sem revelar o significado real do carrinho. No entanto, os exemplos do meu carrinho de compras e do minha mochila, citado em um item anterior, seriam bastante semelhantes em termos de metáforas, ficando claro que a escolha tradutória dos participantes se contrariam. No caso do minha mochila, o tradutor optou por explicar o significado da metáfora sem utilizá-la. Já um terceiro entrevistado relatou disse que faria primeiro o significado da metáfora e, se houvesse tempo disponível, interpretaria a metáfora literalmente.

Em relação a outros termos que poderiam ser considerados ambíguos, um dos participantes citou promoção da acessibilidade. De acordo com ele, promoção é traduzido apenas como desconto na língua de sinais e não no sentido de promover, incentivar. Então, segundo ele: "o surdo, quando ele vai ler o português, 'promoção da acessibilidade' é acessibilidade mais barata. Então promoção é uma palavra que é ambígua". Sempre vai depender do contexto. A palavra acessibilidade também é assim. Enquanto em português têm-se uma única palavra, na Libras existem três sinais diferentes.

\section{5) Em relação à polissemia e à homonímia}

Segundo os entrevistados, embora hajam diferenças entre as duas línguas, o tradutor fará escolhas tradutórias para o que for dito em português seja traduzido para Libras. De acordo com um dos intérpretes "o contexto ajudará na definição do termo", pois, "o que é possível dizer em uma língua, é possível dizer em outra, sempre". Um dos participantes mencionou o sinal de acessar como exemplo. Para ele, esse sinal seria ambíguo, já que representaria o ato de se entrar em algum lugar físico, diferentemente do que ocorre na web. Para evitar esse tipo de equívoco, o tradutor buscaria por outros termos em língua de sinais, como clique e abra e amplie, já que o equivalente direto, neste caso, não seria adequado. No dicionário Novo Deit-Libras (CAPOVILLA; RAPHAEL; MAURICIO, 2009) o termo acessar não foi encontrado, apenas o termo acesso, que é utilizado para ingresso, alcance ou entrada. Porém,
Realização:

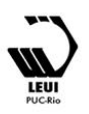




\section{$16^{\circ}$ \\ ERGODESIGN USIHC CINAHPA}

$16^{\circ}$ Ergodesign - Congresso Internacional de Ergonomia e Usabilidade de Interfaces Humano Tecnológica: Produto, Informações Ambientes Construídos e Transporte

$16^{\circ}$ USIHC - Congresso Internacional de Ergonomia e Usabilidade de Interfaces Humano Computador

CINAHPA | 2017 - Congresso Internacional de Ambientes Hipermídia para Aprendizagem. não há menção ao termo utilizado para sistemas da web. Outros exemplos citados foram os termos janela, alimentar e salvar em que o

tradutor/intérprete sugeriu abrir + quadro, colocar e guardar, respectivamente. Outros exemplos de termos polissêmicos sem sugestões de traduções foram nuvem, home, contato, galeria, wallpaper, disco, servidor, janela e portal. Uma questão frisada é que sempre é necessário conhecer o contexto para realizar a tradução.

\section{6) Em relação à palavras traduzidas por um único} sinal (por exemplo, saúde, sadio e saudável)

Em algumas situações existem mais palavras em português do que os respectivos sinais em Libras, a exemplo de bonito, belo e lindo, que em Libras, há apenas o sinal de bonito. Neste caso, o tradutor optou por utilizar o sinal de bonito com diferentes intensidades, como esclarece neste trecho: "vai depender da intensidade que eu vou usar, por exemplo, eu quero fazer lindo, eu vou ter que dar mais intensidade para o mesmo sinal".

Há casos em que o contexto esclarece a sinalização. Ele é necessário para se escolher o termo mais apropriado, como, por exemplo, com os termos saúde, saudável e sadio, que compartilham o mesmo sinal. Esclarece o tradutor: "sadio pode ser uma pessoa que está bem. $\mathrm{Na}$ lingua de sinais eu posso incluir o gênero, posso incluir pessoa saudável, existe uma forma de diferenciar". Então sugere que, na língua de sinais, outros termos sejam utilizados em conjunto para esclarecer o contexto: "dependendo do contexto eu vou acrescentar mais um sinal, mais uma informação, para realmente dizer é saudável, a pessoa era saudável. Eu usaria o mesmo sinal, porém eu ia fazer referências a coisas ou objetos, sujeitos diferentes, e aí vai criando sentido". Outros intérpretes confirmam: "se é saúde, por exemplo, pode-se utilizar o sinal de 'área' para identificar a área da saúde. Já o saudável, pode-se utilizar o sinal de 'pessoa + saúde', dando um contexto para o sinal. O sinal de sadio você pode dar o contexto - 'ele doente nada, saúde forte tem' - dando a significação da palavra 'sadio".

\section{7) Em relação às estruturas hierárquicas como}

\section{forma de diminuir as ambiguidades existentes}

De acordo com 10 dos 11 entrevistados, a hierarquia consegue diluir as ambiguidades, fornecendo um contexto, por meio da ligação entre os links e da estrutura visual, como confirma esse trecho: "primeiro que essa organização hierárquica é visual. Visualmente se dá conta disso". A hierarquia não seria um problema para o surdo, exceto para aquele que "não teve acesso à informação, não domina a língua de sinais, não é alfabetizado...". Dessa forma, não seria necessário adicionar o sinal de pessoa ao de saúde para dizer saudável, pois "se o sinal estiver solto ele vai estar conectado a outro link, então eu acho que não tem dificuldade em deixar um sinal desse tipo isolado".

Assim, não seria necessário acrescentar o sinal de curso para história neste exemplo: "se eu estou em um site que está falando sobre disciplinas ou cursos e daí lá já tem o sinal de cursos. Ele sabe que está em uma página olhando isso, e eu digo assim 'história', 'geografia', não vai confundir com outra coisa. Ele vai saber que é 'história'. Eu não preciso dizer 'curso história". Da mesma maneira em um site de um supermercado, em que sábado e laranja são traduzidos pelo mesmo sinal, a hierarquia seria capaz de diluir a ambiguidade, como relatam: "a pessoa surda que vai acessar o site e vai ter a categorização das frutas, ela vai saber que aquele sinal que está sendo feito ali não é o sinal de sábado, é o sinal de laranja". Isso porque vai-se de uma categoria maior à uma categoria menor, que ajuda a contextualizar o website, conforme explica esse fragmento: "primeiro eu vou para a categoria maior, de frutas, e depois dela é que eu vou descrever o que tem dentro, 'maçã', 'banana', 'laranja'. Então eu acho que, por isso, eu não precisaria criar nenhum outro tipo de estrutura frasal em língua de sinais que desse a entender que é laranja e não é sábado, por exemplo". Já em alguns casos, quando o contexto aproxima sábado e laranja, como na frase "comendo sábado laranja", aí sim, neste caso é necessário utilizar a estratégia fruta laranja.

Dois entrevistados mencionaram a imagem como elemento para diminuir a polissemia, pois se houvesse uma figura de laranjas ao lado do sinal de laranja, não haveria dúvida de que se trataria do
Realização:
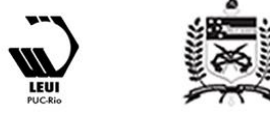


\section{$16^{\circ}$ \\ ERGODESIGN USIHC CINAHPA}

sinal da fruta e não do sinal de sábado. Porém, em alguns casos a imagem também poderia gerar mais incertezas caso não seja representativa: "às vezes, eu acho que os ícones não são tão universais quanto se imagina que são. (...) Visualmente, a gente procura pela imagem. Muitas vezes aquela imagem não corresponde muito bem".

\section{8) Em relação à inclusão de informações adicionais, além do termo traduzido}

Nove tradutores/intérpretes foram favoráveis à inclusão de informações adicionais além do termo traduzido para que o surdo possa tomar decisões, optar entre um link e outro, como esclarece esse fragmento: "precisa estar clara essa informação para ele poder optar. Eu vou para cá ou eu vou para lá? Eu vou escolher mais itens para o meu carrinho ou eu vou encerrar a compra? Então isso precisa estar claro". Essas informações, no entanto, "teriam que ser informações curtas e pontuais para não se tornar cansativo". Uma opção seria "a utilização de imagens para ajudar a diminuir a polissemia e homonímia".

\section{9) Em relação ao uso de tradutores automáticos em um website}

Os entrevistados concordam que atualmente os tradutores automáticos ainda não suportam a complexidade da língua, já que possuem um banco de dados limitado e realizam a tradução de palavras para sinais, e não de sentenças inteiras para a estrutura lógica da língua de sinais. Além disso, "o tradutor automático nem sempre manifesta expressões faciais e muitas vezes não interpreta a Libras e sim um português sinalizado [...], nem sempre compreende as nuances da língua, as metáforas, as figuras de linguagem e as próprias linhas tênues entre língua portuguesa e Libras". Eles também reforçam que para que um tradutor automático seja eficiente ele terá que possuir um banco de dados gigante, com uma ampla combinação de frases e sentenças, e utilizar memória de tradução, de maneira a identificar o contexto e aplicar o termo corretamente, como explica um dos intérpretes: "por exemplo, 'promoção de acessibilidade' já foi traduzido em vários textos de tal forma, então, quer dizer que essa promoção não é desconto. É incentivo, $16^{\circ}$ Ergodesign - Congresso Internacional de Ergonomia e Usabilidade de Interfaces Humano Tecnológica: Produto, Informações Ambientes Construídos e Transporte

$16^{\circ}$ USIHC - Congresso Internacional de Ergonomia e Usabilidade de Interfaces Humano Computador

CINAHPA | 2017 - Congresso Internacional de Ambientes Hipermídia para Aprendizagem. divulgação".

Os participantes acreditam que o tradutor automático seja um recurso, que pode ser utilizado na ausência de um tradutor/intérprete humano, mas para o tradutor automático ainda "falta um pouco de discernimento de saber, de entender que aquele sinal não pode ser usado naquele contexto. Ele pode até traduzir, mas não vai ser uma tradução, ela vai ser uma tradução com algum erro de estrutura, alguma palavrinha diferente, por exemplo". Portanto, por trás desse tradutor automático sempre haverá o trabalho de um tradutor humano para corrigi-lo e aperfeiçoá-lo. Além disso, o design dos avatares deve levar em conta a usabilidade. O uso de muitas cores e o formato dos dedos muito grande podem impedir que o sinal apareça. $\mathrm{O}$ vídeo deve ter boa resolução e ser fluido, sem interrupções, de modo que a sinalização fique clara, nítida.

\section{0) Em relação ao uso do SignWritting em um} website

Todos os participantes concordam que a comunidade surda, em sua maioria, não domina a escrita de sinais: "a maioria dos surdos não tem acesso, não a usa", especialmente porque não é ensinada na escola. Um dos intérpretes esclarece: "os surdos são alfabetizados na gestualidade da língua e não na escrita". Só tem contato com a língua de sinais quem está no meio acadêmico, especificamente na UFSC, ou frequenta alguma das pouquíssimas escolas de educação básica que ensinam o SignWritting.

O uso do SignWritting atualmente serve mais como uma forma de divulgação dessa escrita do que propriamente um recurso de acessibilidade, como fica claro neste trecho: "o uso da escrita de sinais hoje é mais uma marca, tipo, de dizer que já tem uma escrita, vamos colocá-la, vamos difundir, do que promover a acessibilidade de fato do site". Portanto, se tivessem que optar entre a linguagem escrita ou gestual de sinais, optariam pela linguagem gestual: "eu te diria vai ter mais acesso, vai ser mais positivo o uso da Libras porque mais pessoas vão se beneficiar. Se colocar só a escrita de sinais e não colocar o vídeo eu acho que muitos, mas de $90 \%$ não vão atingir o objetivo".
Realização:
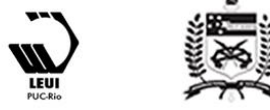


\section{$16^{\circ}$ \\ ERGODESIGN USIHC CINAHPA}

\section{Discussão e conclusão}

Este artigo descreveu a primeira etapa de uma pesquisa que visava a elaborar recomendações para a criação de websites voltados para o público surdo. Nesta primeira etapa foi realizada uma entrevista semiestruturada que objetivava coletar relatos de tradutores/intérpretes sobre quesitos elencados na revisão da literatura. Dentre os resultados obtidos, pode-se destacar as funções de linguagem referencial ou denotativa e emotiva ou expressiva como mais citadas entre os intérpretes para uso em websites para surdos; o cuidado com o uso de regionalismos; a aproximação com a língua de chegada do público surdo; a importância do uso de exemplos e de recursos visuais; a usabilidade da janela em Libras; o uso concomitante da Libras com o português; o uso de equivalentes para evitar ambiguidades causadas por termos ambíguos, polissêmicos, homonímicos e metafóricos; a combinação de sinais para traduzir uma única palavra em português, exceto em estruturas hierárquicas; a inclusão de pistas para facilitar a navegação, porém curtas e pontuais; a utilização de tradutores automáticos e do SignWritting com cautela, uma vez que os tradutores mecanizados ainda não suprem a complexidade da língua de sinais e o SignWritting ainda não é uma escrita difundida entre os surdos.

Com base nesses resultados, pôde-se dar continuidade à pesquisa e avançar para as etapas previstas no início do artigo. Espera-se que esta pesquisa contribua para que os surdos tenham acesso aos websites de maneira mais adequada com a sua língua e cultura.

\section{BIBLIOGRAFIA}

BASTIEN; SCAPIN. Critérios Ergonômicos para Avaliação de Interfaces Homem-Computador. 1993. Disponível em:

<http://www.labiutil.inf.ufsc.br/CriteriosErgonomicos/A bertura.html>. Acesso em: 2 ago. 2016.

BIDARRA, J.; MARTINS, T. O problema da ambiguidade lexical para a interpretação envolvendo a $16^{\circ}$ Ergodesign - Congresso Internacional de Ergonomia e Usabilidade de Interfaces Humano Tecnológica: Produto, Informações Ambientes Construídos e Transporte

$16^{\circ}$ USIHC - Congresso Internacional de Ergonomia e Usabilidade de Interfaces Humano Computador

CINAHPA | 2017 - Congresso Internacional de Ambientes Hipermídia para Aprendizagem.

língua portuguesa e libras. Anais do SIELP, Uberlândia, v. 2 , n. 1 , p. $1-20,2012$.

BRASIL. Decreto no 5.626, de 22 de dezembro de 2005. Regulamenta a Lei no 10.436 , de 24 de abril de 2002, que dispõe sobre a Língua Brasileira de Sinais - Libras, e o art. 18 da Lei no 10.098, de 19 de dezembro de 2000. Lex: Presidência da República. Casa Civil. Subchefia para assuntos jurídicos.

BRASIL. Ministério da Justiça. Secretaria Nacional de Justiça. A classificação indicativa na língua brasileira de sinais. Brasília: SNJ, 2009. 36 p.

CAPOVILLA, F. C.; RAPHAEL, W. D.; MAURICIO, A. C. Novo deit-libras: dicionário enciclopédico ilustrado trilíngue da língua de sinais brasileira, baseado em linguística e neurociências cognitivas. São Paulo: EDUSP, 2009. 2v.

DEBEVC, M.; KOSEC, P.; HOLZINGER, A. Elearning accessibility for the deaf and hard of hearing: practical examples and experiences. In: LEITNER, G; HITZ, M.; HOLZINGER, A. (Org.). HCI in Work and Learning, Life and Leisure. Berlin: Springer-verlag Berlin Heidelberg, 2010. v. 6389. p. 203-213.

DEBEVC, M.; KOSEC, P.; HOLZINGER, A. Improving multimodal web accessibility for deaf people: sign language interpreter module. Multimedia Tools And Applications, Estados Unidos, v. 54, p.181199, ago. 2011.

DIAS, A. R. O conhecimento da marca nas organizações: modelo de aplicação da linguagem publicitária na intranet - PUBLIMARCA. 2014. 195 p. Tese (Doutorado em Engenharia e Gestão do Conhecimento) - Universidade Federal de Santa Catarina, Florianópolis, 2014.

FAJARDO, I.; ABASCAL, J.; CAÑAS, J. J. Bridging the Digital Divide for deaf signer users. In: EUROPEAN CONFERENCE ON COGNITIVE ERGONOMICS: THE ERGONOMICS OF COOL INTERACTION, 15., 2008, Funchal. Proceedings... Nova York: ACM, 2008. p. 1-6.

FAJARDO, I.; ABASCAL, J.; CAÑAS, J. J. The role of working memory and long term memory in deaf users' hypertext navigation: review of guidelines for web accessibility. In: STARY, C.; STEPHANIDIS, C. UserCentered Interaction Paradigms for Universal Access in the Information Society. 8th ERCIM Workshop on User Interfaces for All. Viena, 2004, v. 3196, p. 320-325.
Realização:
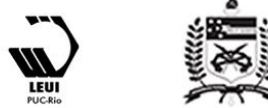


\section{$16^{\circ}$ \\ ERGODESIGN USIHC CINAHPA}

FAJARDO, I., et al. Hyperlink format, categorization abilities and memory span as contributors to deaf users hypertext access. Journal of Deaf Studies and Deaf Education, Estados Unidos: Oxford University Press, v. 13, n. 2, p. 241-256. 2008.

FAJARDO, I.; PARRA, E.; CAÑAS, J. J. Do sign language videos improve web navigation for deaf signer users? Journal of Deaf Studies and Deaf Education, v. 15, n. 3, p. 242-262, mar. 2010.

FLOR, C. S. Recomendações para a criação de pistas proximais de navegação em websites voltadas para surdos pré-linguísticos. 2016. 336 p. Tese (Doutorado em Engenharia e Gestão do Conhecimento) - Programa de Pós-graduação em Engenharia e Gestão do Conhecimento, Universidade Federal de Santa Catarina, Florianópolis, 2016.

FLOR, C. S.; VANZIN, T.; ULBRICHT, V. Recomendações da WCAG 2.0 (2008) e a acessibilidade de surdos em conteúdos da web. Revista Brasileira de Educação Especial, Marília, v. 19, n. 2, p. 161-168, abr./jun. 2013.

GONDIM, S. M. G.; FICHER, T. O discurso, a análise de discurso e a metodologia do discurso do sujeito coletivo na gestão intercultural. Cadernos Gestão Social, Salvador, v. 2, n. 1, p.09-26, set./dez. 2009.

INSTITUTO FEDERAL DE SANTA CATARINA. Site do Câmpus Palhoça Bilíngue. Disponível em: $<$ http://www.palhoca.ifsc.edu.br/index.php>. Acesso em: 30 abr. 2015.

JAKOBSON, R. Linguística e Poética. In: JAKOBSON, R. Linguística e comunicação.Tradução de Izidoro Blikstein e José Paulo Paes. São Paulo: Cultrix, 1987.

MARTINS, T. A. Um estudo descritivo sobre as manifestações de ambiguidade lexical em libras. 2013. 159 f. Dissertação (Mestrado em Letras) - Universidade Estadual do Oeste do Paraná, Cascavel, 2013.

NASCIMENTO, S. P. F.; NASCIMENTO, C. B. Introdução aos estudos linguísticos: língua de sinais brasileira e língua portuguesa em foco. Florianópolis: UFSC, 2010. 68 p.

NORMAN, D. A. O design do dia-a-dia. Rio de Janeiro: Rocco, 2006. 271 p.

OTTAVIANO, S., et al. The deaf and online comprehension texts, how can technology help? In:
MIESENBERGER et al. Computers Helping People with Special Needs. Austria: Springer-Verlag Berlin Heidelberg, 2010. v. 6180, p. 144-151.

PEREIRA, M. C. C. Leitura, escrita e surdez, 2. ed. São Paulo: FDE, 2009. 104 p.

PERLIN, G. T. T. Identidades surdas. In: SKLIAR, C. (Org.). A surdez: um olhar sobre as diferenças. 6. ed. Porto Alegre: Mediação, 2012. p. 51-73.

PERLIN, G. T. T.; STROBEL, K. Fundamentos da educação de surdos. Florianópolis: UFSC. 2006.

PREVENÇÃO DOS PROBLEMAS RELACIONADOS AO USO DE DROGAS. Site do Programa de

Prevenção dos Problemas Relacionados ao Uso de Drogas. Disponível em:

<http://conselheiros6.nute.ufsc.br/libras/>. Acesso em: 30 abr. 2015.

QUADROS, R. M.; KARNOPP, L. B. Língua de sinais brasileira: estudos linguísticos. Porto Alegre: Artmed, 2004.

QUEVEDO, S. R. P. Narrativas hipermidiáticas para ambiente virtual de aprendizagem inclusivo. 2013. 379

f. Tese (Doutorado em Engenharia e Gestão do Conhecimento) - Programa de Pós-graduação em Engenharia e Gestão do Conhecimento, Universidade Federal de Santa Catarina, Florianópolis, 2013.

ROSA, K. A. V.; BIDARRA, J. Português versus libras: os problemas de tradução e interpretação. In: ENCONTRO DO CELSUL, 10., 2012, Cascavel. Anais... Cascavel: UNIOESTE, 2012. p. 1-12.

ROSA, K. A. V. O impacto da ocorrência de palavras ambíguas em português no processo tradutório para libras via glosas: o caso da palavra "estado". 2014. 112 f. Dissertação (Mestrado em Letras) - Universidade Estadual do Oeste do Paraná, Cascavel, 2014.

UNIVERSIDADE FEDERAL DE SANTA

CATARINA. Site do curso de Letras Libras. Disponível em: <http://www.libras.ufsc.br/>. Acesso em: 30 abr. 2015.

VESTEGAARD, T.; SCHRODER, K. A linguagem da propaganda, 4. ed. São Paulo: Martins Fontes, 2004. $274 \mathrm{p}$.
Realização:
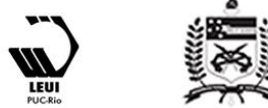